\title{
Experimental Behaviour of Tensile Properties of Aa2014-T6 Aluminium Alloy using FSW and Gtaw Process
}

\author{
B. V. R. Ravi Kumar, A.Sudheer Raja, K. Vijaya Krishna Varma
}

\begin{abstract}
In the bringout research work carried out the comparative study of weld characteristics of Aluminium Alloy AA2014-T6 weldments, joined by employing two processes namely Friction Stir Welding (FSW) and Gas Tungsten Arc Welding (GTAW). FSW was performed with three different geometrical tool pin profiles like triangular, square, pentagon with process variables like tool rotational speed of 1400rpm, traverse speed of $86 \mathrm{~mm} / \mathrm{min}$ and tool tilt angle $3^{\circ}$. GTAW process was carried out by using constant current welding (CCW) and pulse current welding (PCW) at a frequencies of $2 \mathrm{~Hz}$ and $4 \mathrm{~Hz}$ respectively. This work lead to study the Ultimate Tensile Strength (UTS), 0.2\%Yield Strength (YS) and \% Elongation (\%EI) of AA2014-T6 weldments produced by FSW and GTAW.
\end{abstract}

Keywords:Aluminium Alloy 2014-T6, FSW, GTAW, UTS, $0.2 \%$ YS, \% El.

\section{I.INTRODUCTION}

FSW is a novel solid condition joining process in which two abutting surfaces are joined together by means of Unconsumable rotating tool pin along the weld length. Precipitate strengthened and age hardenable aluminium alloy AA2014 gathered wide acceptance in aerospace and defense applications. In GTAW arc is produced by employing non-consumable tungsten electrode besides inert gases on contrary Ar (Argon) or He (Helium) gases is used to prevent the weld from contamination and debris. In this two welding processes is used i.e. Constant Current Welding and Pulse Current Welding.

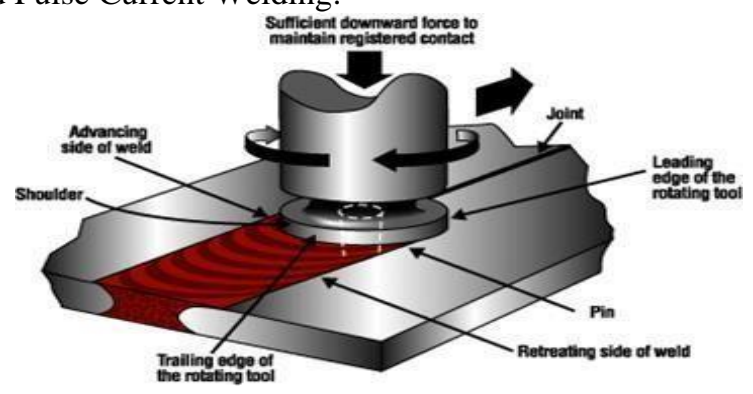

Fig 1.Schematic working of FSW process. [1]

Revised Manuscript Received on December 30, 2019.

* Correspondence Author

Dr. B. V. R. Ravi Kumar, Professor \& Head, Department of Mechanical Engineering, VNR VignanaJyothi Institute of Engineering and Technology, Bachupally, Hyderabad, India.

Mr. AusaliSudheer Raja, PG Scholar, Advanced Manufacturing System (AMS) VNR Vjiet, Hyderabad, India.

Mr. K. Vijaya Krishna Varma, PG Scholar, Advanced Manufacturing System (AMS) VNR VJIET, Hyderabad, India

(C) The Authors. Published by Blue Eyes Intelligence Engineering and Sciences Publication (BEIESP). This is an open access article under the CC BY-NC-ND license (http://creativecommons.org/licenses/by-nc-nd/4.0/)

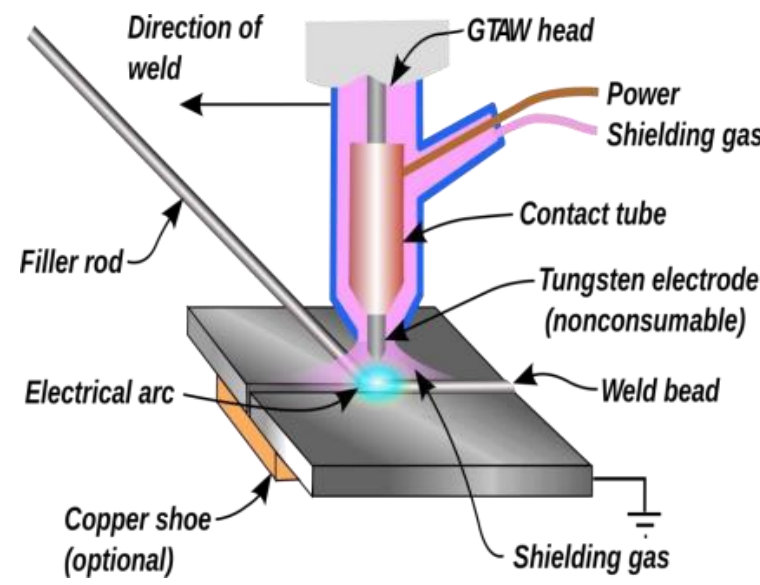

Fig 2. Working principle of GTAW process. [2]

II. MATERIAL AND EXPERIMENTAL
WORK

\section{A. Material}

AA2014-T6 blank was cut on shearing machine and brought to require size of $125 \mathrm{~mm} \times 125 \mathrm{~mm} \mathrm{x} 6 \mathrm{~mm}$. The Spectroscopy analysis and Mechanical properties of AA2014 are shown in Tables 1and 2.

Table 1: Chemical Composition of AA2014 (Wt \%)

\begin{tabular}{|c|c|c|c|c|c|c|c|c|}
\hline $\mathrm{Cu}$ & $\mathrm{Si}$ & $\mathrm{Mg}$ & $\mathrm{Mn}$ & $\mathrm{Fe}$ & $\mathrm{Ti}$ & $\mathrm{Zn}$ & $\mathrm{Cr}$ & $\mathrm{Al}$ \\
\hline 4.1 & 0.7 & 0.5 & 0.5 & 0.1 & 0.0 & 0.0 & 0.0 & $\mathrm{Ba}$ \\
1 & 6 & 9 & 3 & 3 & 6 & 4 & 8 & $\mathrm{l}$ \\
\hline
\end{tabular}

Table 2: Mechanical Properties of AA2014

\begin{tabular}{|c|c|c|}
\hline UTS (Mpa) & $\begin{array}{c}0.2 \text { Y.S } \\
\text { (Mpa) }\end{array}$ & $\%$ El \\
\hline 480 & 370 & 3 \\
\hline
\end{tabular}

\section{B. Experimental Work by Employing FSW}

HMT conventional vertical milling machine (VMM) was employed to fabricate the weldments as shown in Fig 3. AA2014 has to be employed for carrying out FSW.

Three different pin profiles (triangle, square and pentagon) as shown in Fig. 5 with plunge depth of 5 mmwas maintained throughout the entire weld paths shown in Fig 4. Process variables like tool rotation speed $1400 \mathrm{rpm}$, transverse speed $86 \mathrm{~mm} / \mathrm{min}$ and 30 tool tilt angle was maintained throughout the entire weld length. 


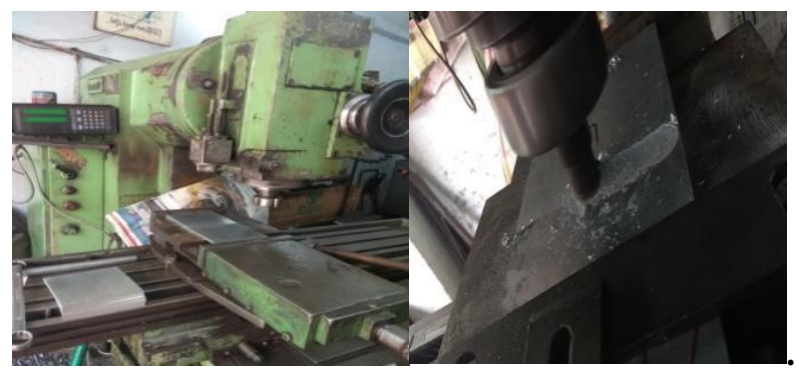

Fig. 3HMT VMM Fig4. FSW Process

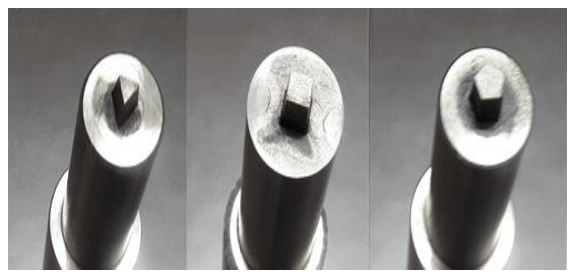

(i)Triangle (ii) Square (iii) Pentagon

Fig 5. FSW Tool Pin Profiles

\section{Experimental Work by Employing GTAW}

Ibell make IGBT machine was used to perform GTAWon AA 2014-T6 weldments. Grooving is done with an angle of 450 and maintain the root gap and root face of $2 \mathrm{~mm}$. ER4043 filler wire of $2.4 \mathrm{~mm}$ diameter and 1000mm length, Shielded Argon gas with flow rate of $8 \mathrm{~L} / \mathrm{min}$, welding voltage of $20 \mathrm{~V}$ and weld speed of $1 \mathrm{~mm} / \mathrm{sec}$ was maintained constant for all the weldments as shown in Fig. 6 and 7

Table 3: Chemical Composition of Filler Wire ER4043

\begin{tabular}{|c|c|c|c|c|c|c|c|}
\hline $\mathrm{Cu}$ & $\mathrm{Si}$ & $\mathrm{Mn}$ & $\mathrm{Mg}$ & $\mathrm{Fe}$ & $\mathrm{Cr}$ & $\mathrm{Ti}$ & $\mathrm{Al}$ \\
\hline 0.17 & $4.5-6$ & 0.24 & 0.05 & 0.05 & 0.05 & 0.05 & $\mathrm{Bal}$ \\
\hline
\end{tabular}

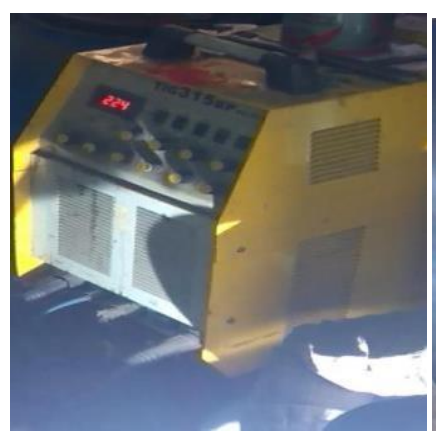

Fig 6. GTAW Machine

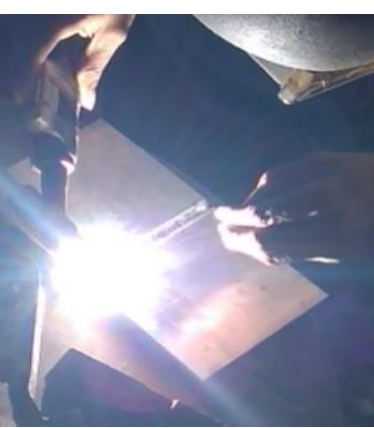

Fig 7.GTAW Process
As per ASTM E8, the tensile specimen (Fig. 8) were made using CNC wire cut EDM. The extracted tensile test specimens from the weldments were joined by FSW and GTAW processes as represented in Fig 9 and 11. The broken tensile test specimen of FSW and GTAW processes as represented in Fig. 10 and 12

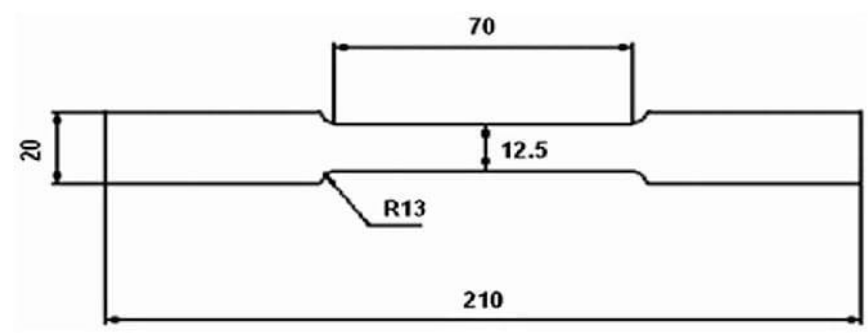

Fig 8. ASTME E8 tensile sketched model

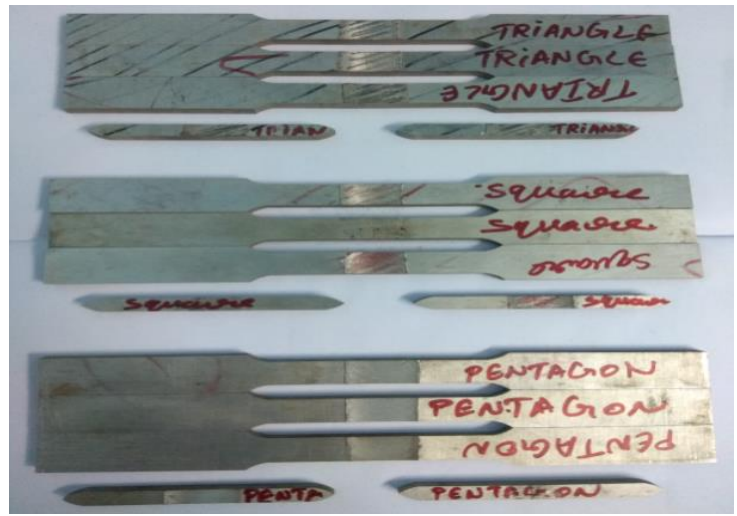

Fig. 9 Tensile specimens extracted fromFSW weldments

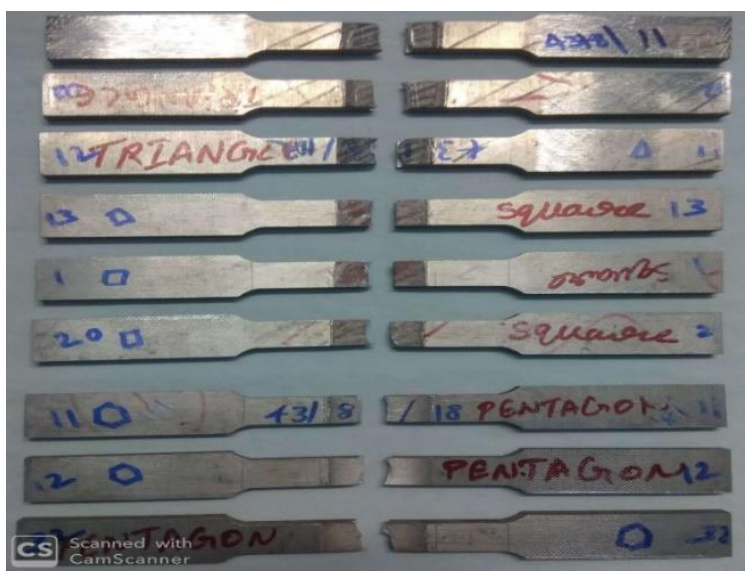

Fig. 10 FSW tensile specimens after performing tensile test on UTM machine

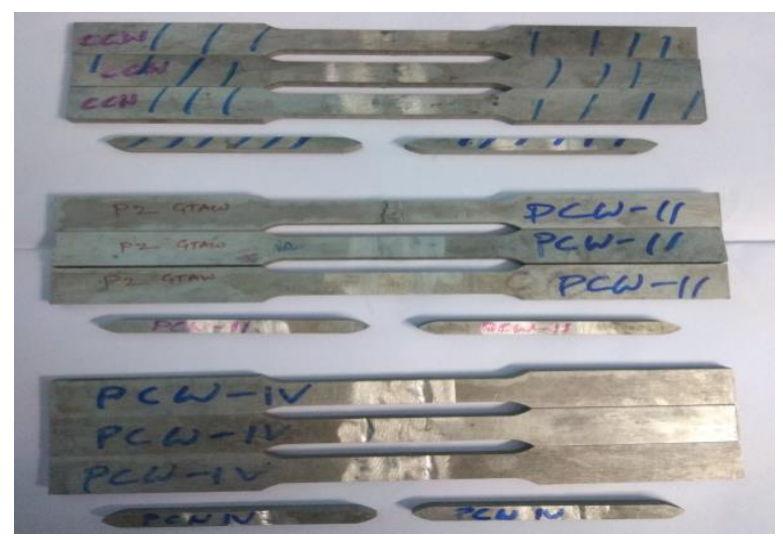

Fig 11.Tensile specimens extracted from

GTAW weldments

Published By:

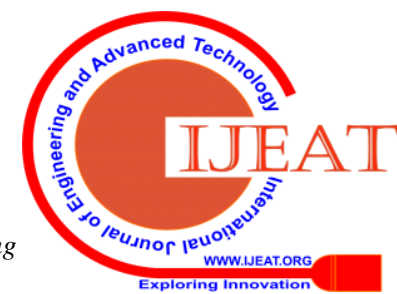




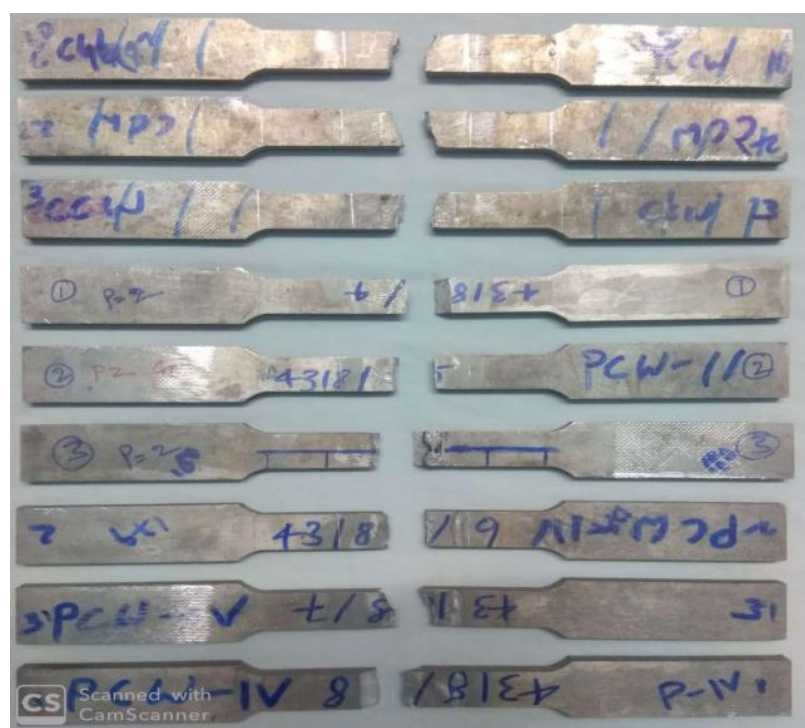

Fig. 12GTAW tensile specimens after performing tensile test on UTM machine

\section{III.RESULTS AND DISCUSSIONS}

Table 4: Tensile properties of the weldments produced by FSW and GTAW.

\begin{tabular}{|c|c|c|c|c|c|c|}
\hline & \multicolumn{2}{|c|}{ FSW tool pin profiles } & \multicolumn{3}{c|}{ GTAW } \\
\hline & $\begin{array}{c}\text { TRIA } \\
\text { NGLE }\end{array}$ & $\begin{array}{c}\text { SQU } \\
\text { ARE }\end{array}$ & $\begin{array}{c}\text { PENT } \\
\text { AGON }\end{array}$ & $\begin{array}{c}\text { CC } \\
\text { W }\end{array}$ & $\begin{array}{c}\text { PC } \\
\text { W } \\
2\end{array}$ & $\begin{array}{c}\text { PCW- } \\
4\end{array}$ \\
\hline $\begin{array}{c}\text { UTS } \\
\text { Mpa })\end{array}$ & $\begin{array}{c}216.5 \\
73\end{array}$ & $\begin{array}{c}211 . \\
321\end{array}$ & $\begin{array}{c}210.36 \\
1\end{array}$ & $\begin{array}{c}104 \\
331\end{array}$ & $\begin{array}{c}15 \\
9.7 \\
62\end{array}$ & $\begin{array}{c}156.9 \\
62\end{array}$ \\
\hline $\begin{array}{c}\text { 0.2 \% } \\
\text { Y.S } \\
\text { (Mpa) }\end{array}$ & 176.7 & 164. & 159.35 & $\begin{array}{c}85.9 \\
83\end{array}$ & $\begin{array}{c}14 \\
9.8\end{array}$ & $\begin{array}{c}141.6 \\
32\end{array}$ \\
\hline $\begin{array}{c}\text { \% } \\
\text { Elong } \\
\text { ation }\end{array}$ & 1.580 & 1.44 & 1.860 & 0.88 & $\begin{array}{c}1.1 \\
6\end{array}$ & 1.78 \\
\hline
\end{tabular}

From the above table 4 during FSW process maximum UTS $216.573 \mathrm{~N} / \mathrm{mm}^{2}$ and $0.2 \%$ Y.S $176.76 \mathrm{~N} / \mathrm{mm}^{2}$ was obtained using triangular tool pin profile and maximum \% Elongation 1.86 was obtained by pentagonal tool pin profile. Minimum UTS $210.36 \mathrm{~N} / \mathrm{mm}^{2}$ and $0.2 \%$ Y.S $159.35 \mathrm{~N} / \mathrm{mm}^{2}$ was obtained using pentagonal tool pin profile and \% Elongation 1.44 was obtained by using square tool pin profile.

From the above table 4 during GTAW process maximum UTS $159.762 \mathrm{~N} / \mathrm{mm}^{2}$ and $0.2 \%$ Y.S $149.819 \mathrm{~N} / \mathrm{mm}^{2}$ was obtained using PCW-2 Hz and maximum \% Elongation 1.78 was obtained by PCW-4 Hz. Minimum UTS 104.33 $\mathrm{N} / \mathrm{mm}^{2}$ and $0.2 \%$ Y.S $85.95 \mathrm{~N} / \mathrm{mm}^{2}$ was obtained using CCW and \% Elongation 0.88 was obtained by CCW.

\section{IV.CONCLUSIONS}

Experimental results shows that;

- In FSW, Triangular tool produces Maximum UTS(216 $\mathrm{Mpa}$ ) and $0.2 \%$ YS (176 Mpa) because of the perfect mixing of the metal in the molten state without voids, blow holes, Lack of penetration and Lack of fusion at the rotational speed $1400 \mathrm{rpm}$.

- In GTAW process, the weldments produced Maximum UTS (159.76 Mpa) in Low pulse current welding i.e. 2 pulse/sec compared to CCW and High pulse current.
Due to the current variations, base current (tb) is less than peak current (tp), due to this difference in temperature, solidification of the weld pool quickly and there is no more changes occurred in grain structure.

- This research work further shown from the results, FSW process produce good mechanical properties compared to the GTAW.

\section{ACKNOWLEDGEMENT}

The authors are thankful to Dr. G.S Gupta, Professor and HOD Mechanical engineering, VNR VJIET, Dr. E.V Ramana P.G Coordinator, MED,VNR VJIET, Raghavendraspectro metallurgical laboratory prashanthinagar, Sri venkateshwara engineering works Fatehnagar, Ravi TIG engineering works Fatehnagar, Teja EDM works bowenpally, Jyothi laboratory Balanagar.

\section{REFERENCES}

1. Muthukrishnan, M., and K. Marimuthu. "Some studies on mechanical properties of friction stir butt welded Al-6082-T6 plates." In Frontiers in Automobile and Mechanical Engineering-2010, pp. 269-273. IEEE, 2010.

2. Zhao et al. "The influence of pin geometry on bonding and mechanical properties in friction stir weld $2014 \mathrm{Al}$ alloy." Materials letters59, no. 23 (2005): 2948-2952.

3. Mishra, Rajiv S., and Z. Y. Ma. "Friction stir welding and processing." Materials science and engineering: R: reports 50, no. 1-2 (2005): 1-78.

4. Patil, H. S., and S. N. Soman. "Experimental study on the effect of welding speed and tool pin profiles on AA6082-O aluminium friction stir welded butt joints." International Journal of Engineering, Science and Technology 2, no. 5 (2010): 268-275.

5. Kumar et al. "An Experimental Investigation to Find Out the Effect of Different Pin Profile Tools on AA 6061 T6 and AA 2014 T4 with Friction Stir Welding." International Journal for Technological Research in Engineering 2 (2015): 1622-1625.

6. https://www.google.com/url?sa=i\&source=images\&cd=\&ved=2ahUK Ewj_jMGsqrfmAhVm6nMBHbw0C8cQjRx6BAgBEAQ\&url=https\% 3A\%2F\%2Fwww.hindawi.com\%2Fjournals\%2Famse\%2F2014\%2F1 05713\%2Ffig1\%2F\&psig=AOvVaw2gJ4_1XfqyzmeDleQHckDA\&u st $=1576488191513492$

7. https://www.google.com/url?sa=i\&source=images\&cd=\&ved=2ahUK EwiUrZPSqrfmAhV-

63MBHS6tCZEQjRx6BAgBEAQ\&url=https\%3A\%2F\%2Fen.wikipe dia.org\%2Fwiki\%2FGas_tungsten_arc_welding\&psig=AOvVaw1oarj dmpGQodQHIxRJOhIE\&ust=1576488280297156

\section{AUTHORS PROFILE}

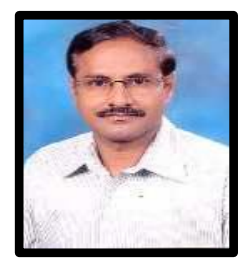

Dr. B.V.R Ravi Kumar, received his M.Tech., Design \& Production Engineering-Machine Tools) from REC ( Now, National Institute of Technology), Warangal during 1996-98. He is working as Professor and Head of Competency Development Center (CDC) in the department of Mechanical Engineering at VNR VignanaJyothi Institute of Engineering and Technology, Bachupally, Hyderabad. He published more than 70 journals in both national and international conferences. He is the life member of various professional bodies like The Institution of Engineers (India), Indian Welding Society (IWS) and Society for Aerospace Quality and Reliability (SAQR) and Indian Society of Technical Education. 


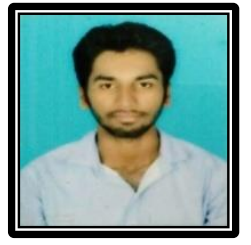

Mr. AusaliSudheer Raja, is a PG scholarin Advanced Manufacturing System (AMS) from VNR VJIET, Hyderabad. His area of research work is in comparison of FSW and GTAW.

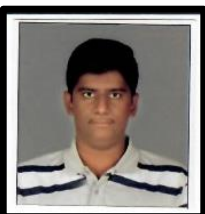

Mr. K.Vijaya Krishna Varma, is a PG scholarin Advanced Manufacturing System (AMS) from VNR VJIET, Hyderabad. His area of research work is on welding of aluminum alloys using FSW 